\title{
ACKNOWLEDGEMENTS
}

In many ways, this book is the outcome of years of researching and writing on the subject of the white woman in colonial India. However, this particular book was completed in a specifically challenging context of setbacks, heavy teaching schedule and onerous administrative responsibilities, which all seemed to come together. It is all the more so that while completing it, I have incurred innumerable debts of goodwill, help and support from friends and well-wishers.

My young friends, Manu, Samiksha and Saurabh, former students who are young teachers themselves today, tracked down electronic journals and read earlier drafts of chapters in the midst of their own busy schedules. Without them this book just would not have fructified. To Waltraud, a warm thank you for her encouragement over the years and especially for her support for this book. Thanks to Ranjana for sharing rare research materials, and to Amar, Lata, Menka, Parimala, Partho, Prasun, Shashank and Shilpi for sustaining me with their friendship, help and interest in my work at different stages.

The genesis of this book lay in a Research Award Fellowship awarded by the University Grants Commission which gave me the opportunity to research and mull over fresh dimensions of gender and colonial India, besides giving me leave from Sri Venkateswara College, Delhi University. Various fellowships and grants at different junctures over the years cumulatively contributed towards the shaping of this book. They were crucial in enabling me to access primary materials at that amazing repository, the British Library in London. I gratefully acknowledge here a British Academy Visiting Fellowship, a Visiting Fellowship at Oxford Brookes University, travel grants from the Wellcome Trust and the Indian Council of Historical Research, as well as two academic grants from the Charles Wallace India Trust. In addition, I wish to thank the staff of Sri Venkateswara College Library and the Nehru Memorial Museum and Library at New Delhi, the National Library at Kolkata, the University Library, Cambridge University, the School of Oriental and African Studies library, as well as the Wellcome Library at London.

At Manchester University Press, I am thankful to the series editors for including this book in their Studies in Imperialism Series. I must also express my gratitude to them and also to the anonymous readers of the manuscript for their constructive suggestions and comments. This book has turned out to be the better for them. I wish to extend 


\section{GENDERED TRANSACTIONS}

my sincerest thanks to Emma Brennan for the sustained good-humour, co-operation and patience that she has shown during the finalisation of my book.

Finally, as always, my family members - my sister Nandini, brother Jayanta (Dada), Bhaskar, Chiru, Shubhalaxmi, Alexus - were always there for me. And not to forget little Siddhu and Francis who provided such joy and carefree laughter on their occasional visits from half way across the globe. But of course, as always, it has been Chandan, my dear partner of three decades who has had to bear the brunt of the challenges of this particularly rocky journey. This book is therefore dedicated to him. 